\title{
パルプ産業より見たる原木事情の 現状と見透し*
}

戦後に於ける我が国の経済は幾つかの段階を経て急 速なる成長を遂げ，今日の発卧を見るに至りましたも のの, その成長の動態過程に於きまして甚しい不均衡 と不安定な構造的内容を包含して抢り，産業の伸びを 阻害する素因が漸くめらわになりつつある現状であり ます。

此の時に当りパルプ業界としても其の基礎原料とし て重要不可欠なる原木沉き，現在の状態を㠜視し併 せて将来への動向を推測することは誠汇䇣要なことと 存ずる次第であります。申す⿱であなくパルプ工業の 将来は原木問題に要約されるとまで言われる位であり まして，是れ即ち原料木材を恒続的经县安定価格で 確保する事が最大の眼目であります。

然し原木問題は誠に複雑でありまして一挙に之れが 解決策を結論づけることはなかなか難かしいところで めりますので，一応現状把握を基碟として申上げて見 たいと思います。

扱て我が国の林野面程は国土総面程約 3,730 万町步 に対し 2,500 万町歩で約 $67 \%$ の多きを占めて居ります。 御参考に申しますと, 世界の全森林面積の比率は土地 総面積に対し $29 \%$ に過ぎません。

之れに依りましても，我が国が如何に森林国であり，

第 1 表 木材需給長期見透し総括表

（単位 $: 1,000$ 石）

（林総協資料による）

\begin{tabular}{|c|c|c|c|c|c|}
\hline \multicolumn{2}{|c|}{ 年度 } & 27 & 37 & 47 & 年 \\
\hline \multirow[t]{2}{*}{ 需 } & 針 & 146,699 & 174,902 & 197,213 & 217,699 \\
\hline & 厷 & 92,116 & 100,394 & 111,760 & 122,143 \\
\hline 要 & 壾 & 238,815 & 275,296 & 308,973 & 339,842 \\
\hline \multirow{3}{*}{$\begin{array}{l}\text { 伐 } \\
\text { 採 } \\
\text { 量 }\end{array}$} & 針 & 169,411 & 199,748 & 222,716 & 242,551 \\
\hline & 坛 & 93,623 & 100,273 & 112,866 & 120,474 \\
\hline & 計 & 263,034 & 300,021 & 335,582 & 363,025 \\
\hline \multirow[t]{2}{*}{ 蓓 } & 針 & $3,749,852$ & $3,342,386$ & $2,760,302$ & $2,233,446$ \\
\hline & 広 & $3,422,240$ & $3,259,531$ & $2,936,023$ & $2,414,758$ \\
\hline 謮 & 部 & $7,172,092$ & $6,601,917$ & $5,696,325$ & $4,648,204$ \\
\hline \multirow{3}{*}{$\begin{array}{l}\text { 成 } \\
\text { 長 } \\
\text { 最 }\end{array}$} & 針 & 115,753 & 125,053 & 145,213 & 155,604 \\
\hline & 広 & 89,819 & 86,773 & 78,340 & 65,018 \\
\hline & 計 & 205,572 & 211,826 & 223,553 & 220,622 \\
\hline \multirow{3}{*}{$\begin{array}{l}\text { 過 } \\
\text { 伐 } \\
\text { 度 }\end{array}$} & 針 & $46 \%$ & $60 \%$ & $53 \%$ & $56 \%$ \\
\hline & 広 & $4 \%$ & $16 \%$ & $44 \%$ & $85 \%$ \\
\hline & 部 & $28 \%$ & $42 \%$ & $50 \%$ & $64 \%$ \\
\hline
\end{tabular}

* 原稿受付 34.6 .25

** 東北パルプKK 副社言 昭和 34.5 .15 第 21 回 バルプ人緎技術 研究会の講演)
井 戸川 春 三**

従って森林産物を如何に活用せねばならぬ国であるか と言うことが判ると思います。

次汇蓄積につきましては昭和 31 年 3 月「森林資源 総合対策協議会」(林総協) から発表された資料㳀り ますと昭和 27 年現在に於いて, 針葉樹は約 37 億 5 千 万石, 公葉樹約 34 億 2 千万石, 合計 71 億 7 千万石と なって居ります。

此の蓄積を基にして敏年生長する量, 即ち生長量は, 針葉樹 1 億 1 千 600 万石, 仏葉樹 9 千万石, 計 2 億 600 万石となって扔ります。

之れ汇刘し伐採量は針葉樹 1 億 6 千 900 万石, 広葉 樹 9 千 400 万石, 計 2 億 6 千 300 万石でありますから 生與量と伐採量との差 5 千 700 万石が資源住対する喰 い込みとなって和ります。

言い換えれば生長量の $28 \%$ の過伐と相成ります。

此の生長量と伐採量との差が徐々に大きく開いて行 き今後 23 年後の昭和 57 年頃には 1 億 4 千 200 万石, 即ち $64 \%$ という大きい過伐になるとの見透しを樹て ております。

この推定で参りますと約 72 億石の 現在蓄積は昭和 57 年頃には約 46 億石となり，その隇少率は $36 \%$ 飞当 ります。この減少の内容を見ますと，針葉樹に於いて $40 \%$, 広䒚樹に於いては $30 \%$ 各々減じておりますの で，近い将来に於ける針葉樹資源の減少は誠に憂うべ きものがあると思う次第であります。但し以上の算出 には, 輸入材は含まれて和りませんので南洋材, ソ連 材等の輸入材をなるべく多くする事によりそれだけ伐 採量を，従って過伐度を減少させる事が出来ます。

パルプ工業界に於きましても，早くもこのこと有る を察知し，特に製紙用パルプに於いて，数年前から針 葉樹を広葉樹に転換するため, クラフト法, セミケミ カル法, ケミグランド法等種々製法を新たに致し, 又 従来のサルファイト法に於いても, 広葉樹汇適した蒸 解法を検討して，之れに対処しておる事は既に皆さん の十分御承知の事と存じます。

之れに関連して妶に申し上げ㯰き度いのは造林に就 いてであります。

右に申し述べました針葉樹資源の漸減に対する施策 につきましては現在官民共真剣化研究且つ実施されつ つめります。 
林野庁に於きましても今後の木材需給の緩和には強 力な拡大造林に拠るべきだとし粗悪な雑木林の林種転 換，原野への造林促進などを積極的に取り上げる態度 を明らかに致して扣ります。「林総協」の計画では， 現在, 人工林面積 574 万町歩, 天然林面積 1 千 687 万 町歩，その割合 $25: 75$ でありますが昭和 57 年には人 工林面積は 1 千 000 万町步に增加し，天然林は 1 千 286 万町歩に減じ，その割合 $44: 56$ と比率が逆転する見 透しになっております。

斯様に人工林が増加致しますことは，とりもな招さ ず人工造林の推進の結果であります。

但し妶に御注意願いたいことは，人工造林の内容で あります。

工業用原料としての木材利用も進んで参りましたと は申せ，今日に於きましても未だな扰造林用樹種と言 いますと矢張り杉, 檜, 落葉松等即ち現在として, ハ ルプ原木には不向きとされています樹種が主たるもの であります。

松類の造林となりますと，パルプ業界など特殊な部 門に限られているのは洵に残念であります。

この事は従来より䒠固として未だ抜け切らない建築 用材，即ち杉，檜を主体とした大径木の生産に偏重し ているからであります。こんな状態下に於きましては パルプ原木の量的安定確保は期待薄と相成りますので 自然早期育成林業へ移行推進されざるき得なくなる次 第でして，これが一方法として優良樹種の研究の為, 林野打记於きむして子箖極的涂乘り出し, 昨 33 年度 には全国 5 力所の「林木青種場」を設置着々内容を充 実致さんとしている状態であります。

第2表 イタリアポプラと日本松との生長比較

（ポプラ懇和会資料による）

\begin{tabular}{|c|c|c|c|c|c|c|}
\hline & 年 & 1 年 & 5 & 10 年 & 15 年 & 20 \\
\hline 樹 & イタリアホプラ & $4.0 \mathrm{~m}$ & $12.0 \mathrm{~m}$ & $19.0 \mathrm{~m}$ & $25.0 \mathrm{~m}$ & $29.0 \mathrm{~m}$ \\
\hline 高 & 日 本赤松 & $0.2 \mathrm{~m}$ & $1.4 \mathrm{~m}$ & $4.9 \mathrm{~m}$ & $8.3 \mathrm{~m}$ & $11.5 \mathrm{~m}$ \\
\hline 值 & イタリアポブラ & $0 \mathrm{~m}$ & $0.20 \mathrm{~m}$ & $0.32 \mathrm{~m}$ & $0.42 \mathrm{~m}$ & $0.49 \mathrm{~m}$ \\
\hline 径 & 日本赤松 & $0 \mathrm{~m}$ & $0.01 \mathrm{~m}$ & $0.04 \mathrm{~m}$ & $0.08 \mathrm{~m}$ & $0.12 \mathrm{~m}$ \\
\hline
\end{tabular}

特に近時頓に盛んになりつつありますイタリア系ポ プラの如きは，未だ試験期の段階を脱してはおりませ んが，我が国の風土にも大変良く適応し，成長も頗る 早く，我が国針葉樹の収穫期間の約 $1 / 3$ 程度でほぼ同量 の収穫を上げ得られます。

ポプラの利用に於いて最も歴史もあり進步も致し抒 りますトリノ市を中心としました北部イタリアでは， 新聞紙を主体とした一彆紙会社にて使用原木の $20 \%$ が 針葉樹で，あと $80 \%$ は全部ポプラ材だけで年間 100 万 石以上飞達していると言了如き例もあります。 全体の需給に就きましてはこれ位に致しまして，次
にパルプ業界で使用致しておりますパルプ原木につい て眺めて見ましょう。

第 3 表 年度別パルプ原木消費比率

単位 $: 1,000$ 石

(林野庁林産課調)

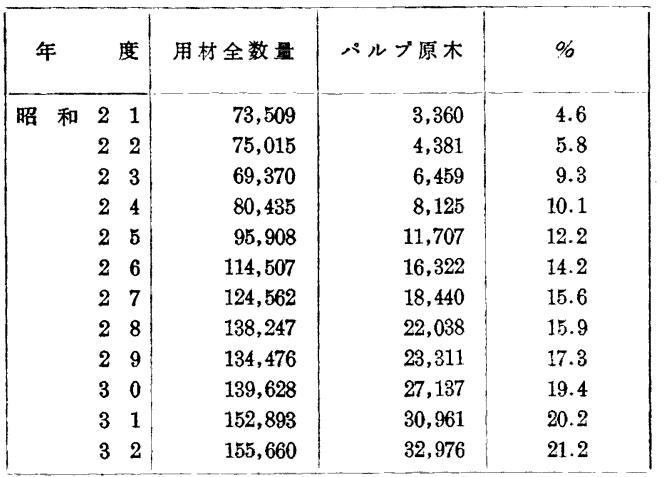

終戦の昭和 20 年, 翌 21 年頃を標準にとるのは少し 無理かも知れませんが，21年のパルプ原木消費量は約 336 万石でした。それが一作昭和 32 年に於きまして は約 3 千 300 万石々飛躍的に増加を致し終戦淔後の約 10倍となっております。

このパルプ原木消費量の全木材消費量汇対する比率 は終戦直後は約 $5 \%$ 過ぎませんでしたが昭和 32 年 に於いては約 $21 \%$ と伸びて怙ります。

第 4 表 主要国パルプ材消費比率

(F.A.O. Yearbook of forest product statistics 1956) 単位: 1,000 石

\begin{tabular}{|c|c|c|c|c|}
\hline & 名 & 総 & パルプ材 & $\%$ \\
\hline$\prime$ & ルウ & $\begin{array}{r}\text { 千石 } \\
41,252\end{array}$ & $\begin{array}{r}\text { 千石 } \\
18,000\end{array}$ & 44 \\
\hline ス & 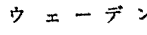 & 147,744 & 61,920 & 42 \\
\hline カ & ナ & 319,482 & 113,731 & 36 \\
\hline 7 & インラント & 143,280 & 39,960 & 28 \\
\hline$\checkmark$ & $x$ & $1,079,676$ & 246,524 & 23 \\
\hline 日 & 本 & 211,104 & 27,162 & 13 \\
\hline
\end{tabular}

然しこの比率を欧米の紙パルプ生産国のそれ，即ち ノルウェー44\%，スウェーデン $42 \%$ ，カナダ $36 \%$, フインランド $28 \%$ ，アメリカ $23 \%$ と此較しますとな お末だしの感があります。

然し之れは畢竟我が国の木材消費が建築材料, 然料 等木材の原始的利用方法に終始し木材を工業原料とし て利用する率が低いからでありまして，将来は先進国 の様に附加価値の高いパルプ等の生産增加を計るとす れば，右比率はまだまだ昇る事となりましょう。

尤子その生産增加には確実な需要の裏付けがなけれ ばなりません。

その一つとしてパルプ価格の 約 $50 \%$ を占める原木 費を低下させ国際貿易競争泟两得る様努力致さねば ならないのでありまして，この辺にも安い広葉樹利用 
の急務が強く推進される所以があります。

御参考汇附加価值の一例を申しますと，木材を単汇， 薪炭材として使用した場合の附加価值を 100 とします そ,

上質紙が 880 (約 9 倍)，スフ系が 1985 (約 20 倍)， 人絹糸が 3120 (約30倍)

と言う大きなものになります。

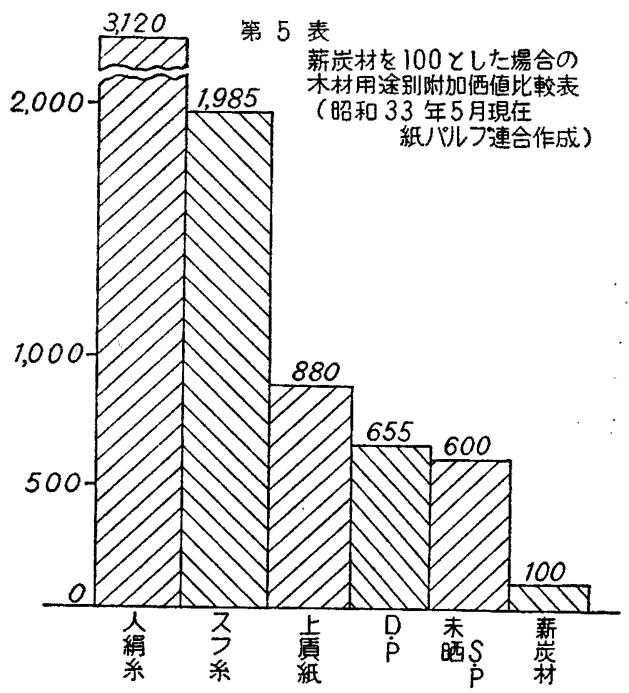

なおパルプ価格に於ける原木費の比重の一例を見ま すと未晒 SP (1958年) に於いて日本では 55\%， ア

\section{第 6 表 末晒 SP価格構成比率}

㾞料：Paper Trade Journal
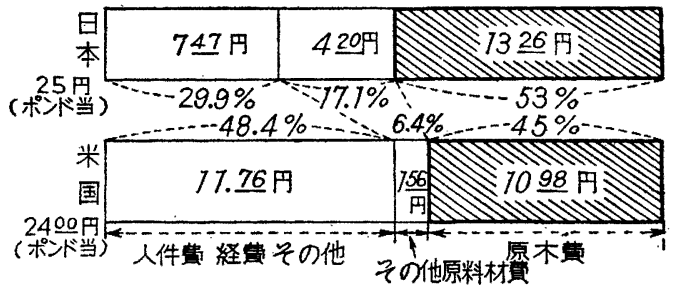

メリカでは $45 \%$ と䄪 $8 \%$ も我が国汇於いて原木費の 割高を示しています。原木費以外の硫黄，石炭等の原 料費を含めますと，日本では70\%，アメリカでは $52 \%$ と約 $18 \%$ あ諸原料高となって赫ります。

次にパルプ原木消費の内容を見まするにそのうち広 葉樹の比率は終戦後数年間は $2 \sim 3 \%$ ありましたも のが昭和 30 年より漸く增加の兆しを見せ,

昭和 30 年 $12 \%, 31$ 年 $15 \%, 32$ 年 $17 \%, 33$ 年 $21 \%$ とそのウェイトを增し，34 年度の計画では $26 \%$ と見
第 7 表 年度別パルプ原木消費量

(単位 $: 1,000$ 石)

(林野庁林産課調)

\begin{tabular}{|c|c|c|c|c|c|c|c|}
\hline 年度 & 総 数 & 内 & & & 構 & 成 & \\
\hline Tli & & & 広 & 原材他 & 針 & 层 & 佣材他 \\
\hline 和21 & 3,360 & 3,100 & 79 & 171 & 92.6 & 2.4 & 5.0 \\
\hline 22 & 4,381 & 4,167 & 87 & 127 & 95.1 & 2.0 & 2.9 \\
\hline 23 & 6,459 & 6,213 & 130 & 116 & 96.2 & 2.0 & 1.8 \\
\hline 24 & 8,125 & 6,647 & 301 & 1,177 & 81.8 & 3.8 & 14.4 \\
\hline 25 & 11,707 & 9,140 & 619 & 1,948 & 82.6 & 5.6 & 11.8 \\
\hline 26 & 16,322 & 12,265 & 587 & 3,470 & 75.1 & 3.6 & 21.3 \\
\hline 27 & 18,440 & 14,427 & 736 & 3,277 & 78.4 & 4.0 & 17.6 \\
\hline 28 & 22,038 & 20,811 & 1,156 & 71 & 94.4 & 5.3 & 0.3 \\
\hline 29 & 23,311 & 21,427 & 1,848 & 36 & 91.9 & 7.9 & 0.2 \\
\hline 30 & 27,137 & 23,929 & 3,149 & 59 & 88.2 & 11.6 & 0.2 \\
\hline 31 & 30,961 & 26,280 & 4,539 & 142 & 84.9 & 14.7 & 0.4 \\
\hline 32 & 32,976 & 27,332 & 5,644 & -1 & 82.9 & 17.1 & -1 \\
\hline 33 & 30,234 & 22,635 & 6,215 & 1,384 & 74.4 & 21.0 & 4.6 \\
\hline
\end{tabular}

但し 32 年度の履材他は針，厷各丸太の中汇含む。

込んで和ります。

但しこの数值は全パルプに就いてでありますが，溶 解用パルプの及に就いて見るに 30 年 $12.3 \% ， 31$ 年 $12.5 \%, 32$ 年 $13.1 \% ， 33$ 年 $13.6 \%$ と殆えど変化がない こと学特汇申し、上げたいと存じます。

この䟃勢は木材洒格が現在に於いて広葉樹が針菒樹 より安いという点に抛ることが大きいのでありますが， 一面広葉樹の奥地遊休資源江莫大汇存在致し，国土開 発乃ち林道の整備に伴い出材の可能性が增大するとい う理由に依るものでして, 樹種別需給調整上より見て も洵に結構なことで今後む益々この方向に進むでしょ うし，又左椂でなくてはなら好存ずる次第でありま s。

兹で私は将来のパルプ材として特に薪炭材のことを 申し上げなければならぬと思います。

それは薪炭材をパルプ材洒換することによって莫 大なるパルプ資源を獲得することが出来るし，また価 格の点より見ましても薪炭材の方がパルプ材より安い ので，当然我々はこれを入手出来る立場にあるからで 岁りす。

薪炭材の伐採量は立木に換算した石数にして第 8 表 の如くなります。

木炭に於きむしては，昭和 21 年 6 千 260 万石であ りましたが 23 年には 8 千 740 万石に增加し，その後 渐減，30 年汇は 5 千 700 万石と逓減して和ります。

薪代於きましては昭和 21 年 9 千 750 万石であり末 したが 23 年の 1 億 900 万石をピークとして以後急激 汇低下し，30年には 6 千 450 万石となりました。

これは即ち，我が国の薪炭原木全体の傾向として減 少汇向いつつあることを現わしております。 
第 8 表 戦後の薪炭材伐採量の推移 （科学技術庁資源局編“日本の森林資源”に抛る） 単位: 1,000 石

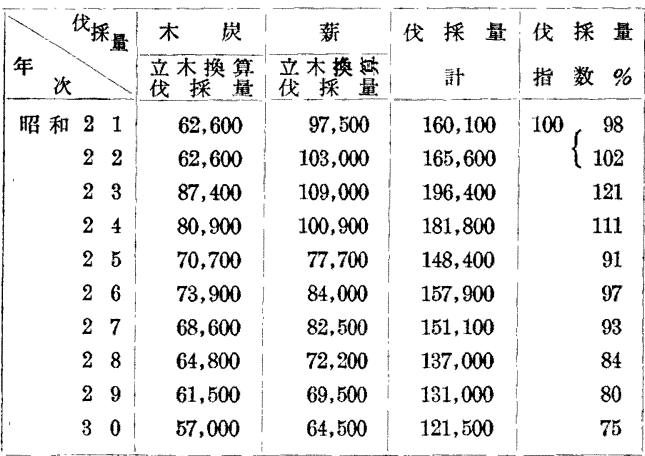

第 8 表の昭和 $21 ， 22$ 年の模炭材立木換算総伐採量 の算術平均を 100 として累年その指数をとりますと， 昭和 23 年の 121 をピークとして漸減し，30 年には75 に下がっております。

これは木炭, 薪に代わるべき手軽な簡易代替然料, 即ち都市ガス，プロパンガス，コークス，业炭，石油， 煉豆炭等が近時急速に広まり, 為に澵炭消費が減退し て来たことを示していると言劣るでしょう。

第 9 表 家庭部門の然料消費指数 （科学技術宁資源局編“日本の森林資源”に拠る）

\begin{tabular}{|c|c|c|c|c|c|c|c|}
\hline 度 & 電 力 & 石 尖 & 岑䙵 炭 & ニークス & 都甫ガス & 石 油 & 炑宣炭 \\
\hline 昭和 26 & 100 & 100 & 100 & 100 & 100 & 100 & 100 \\
\hline 27 & 105 & 99 & 87 & 123 & 112 & 1,390 & 115 \\
\hline 28 & 113 & 101 & 119 & 145 & 130 & 2,430 & 136 \\
\hline 29 & 121 & 109 & 120 & 140 & 148 & 1,880 & 160 \\
\hline 30 & 127 & 119 & 126 & 180 & 165 & 2,070 & 175 \\
\hline 26 害数 & 7,379 & 3,433 & 241 & 40 & 845 & 24 & 160 \\
\hline 単 位 & $10^{5} \mathrm{kWh}$ & $10^{3} t$ & $10^{3} t$ & $103 t$ & $10^{6} \mathrm{~m}^{3}$ & ${ }^{3} \quad 1 \overline{3} \mathrm{kl}$ & $10^{3} t$ \\
\hline
\end{tabular}

この事を裏書きしていると思われますのが第 9 表で まります。薪炭材は殆んど家庭部門の採援とか，付房 用として用いられますが，今，家庭部門の然料のうち 薪炭を除いたものの昭和 26 年以降の消费指数を掍げ た表でして，薪炭を除いた他の各然料の消費がいずれ 增加万至急増致しております。

この薪炭材と申すのが，特殊用途に使う少量は別と

して殆んどが広葉樹であります。

この薪炭材の減少乃至ゆとりの部分はどうなってい るか？それが然料外の用途にふり替りつつあり，そ の一部が既にパルプ原木として流用されている訳であ ります。

初めは薪炭生産業者との間の摩擦も繫念されました が，最近は各社共スムーズに薪炭向き材，即ら広葉樹 小径木を入手されている様であります。
この分野の数量は前述の如く立木石数にして年間約 1 億 2 千万石と言万非常に大きいるのでありますから, 今後もパルプ原木の集荷分野として大いに期待される ところであります。

次に奥地林について申し上げます。

㕕葉樹利用に際してブッつかりますのは奥地林の開 発間題であります。

御承知の如く広葉樹は主として奥地に偏在いたし， これが開発にはいろいろのネックがあります。

その一つが輸送困難，ひいては生産費の高くつく事 であります。また電源開発や農工業用水の利用，など と関連して総合的に考虑計画される必要がありまして 開発の困難性と公共性とが絡んで来る処にも問題があ ります。

然し，この奥地林開発は独り一業界だ壮の問題では なく，大きく林野資源の培羡と国土保全の立場から林 野行政の重要なるポイントでありますので, 農林省に 於きまして子昭和 26 年「森林法」の改正以来, 民有 林道開発の為の助成，低利金の融資等積極的な施策を 講じつつあります。

序ながら申しますと本年の民有林道への補助，融資 の国費総予算は約 40 億円，これに国有林自体の林道 予算が約 80 億円，合計約 120 億円の予算を計上，奥 地林開発に取組儿でいる現状にあります。

斯様な訳で林道網が次第に奥地に入り込んで参りま すにつれ，今迄の不採算林分が採算に乗ることとなり， 従って従来奥地に死藏されて参りました老熟林分子大 いに活用されるに至りましょう。

次に付加え拉きたく思います事は木材チップ並びに 原材の事であります。

広葉樹利用促進と並行してパルプのコスト引下げに 関連し, 近時, 木材チップ及び屑材の活用も漸く軌道 に乗らんとし「紙パルプ連合会」の中にもチップ委員 会を設け，これが推進に努力し一方チップメーカー侧 では「全国木材チップ工業連絡会」並びに「各県チッ プ連絡会」を整備系統化致しつつある状態にあります。 このチップ及び肩材の最近の消費量は昭和 32 年 165 万石, 33 年 280 万石, 34 年 537 万石（見込名）とな って掊りまして，これがパルプ原木消費量に占める比 重は

各々 32 年 $5 \%, 33$ 年 $9 \%, 34$ 年 $14 \%$ となります。

このチップ及び履材は針，広両樹種を含んだもので すが，将来南洋産ラワン材のチップ及び㕍材がパルプ 原料として利用される様になると，用材として年間 900 万石以上も輸入されて居りますので, それから出 
る㕍材も莫大な量汇上り，從って広葉樹チップの使用 も大い增加する訳で，今後チップ工業の技術及び系 列化の進行と共に益々チップ使用が多くなって参るも のと想像されます。

以上申し上げました事を要約致しますと，我が国の 既存のパルプ資源は楽観を許さないのでありますが， 特隹針葉樹資源にの及依存していては遂に行き詰りを 来たす事は最早や自明の処でありますので，どうして も広葉樹をより多く使ってこの危機を脱し旁々造林の 抎充, 外材の輸入等によって将来の解決を計ることが 最も急務であると存ずる次第であります。

最後に当り，先に申し上げた様に，製紙用パルプは 年々急激な勢いで広葉樹に転換しつつありますが，溶 解用パルプに於いては遺情作ら未だしの感があります ので, 本日御列席の皆さんは既御承知の事と存じま すが，更に認識を新にして戴くために広葉樹が溶解用 パルプ原木としてあながち針葉樹に劣るものではない 有用資源であること，及び広葉樹パルプの特徴沉い て簡単に御説明申し上げ度いと存じます。

第10表 主要パルプ材組成

（右田：パルプ及び製紙工業実験法 P. 176 177）

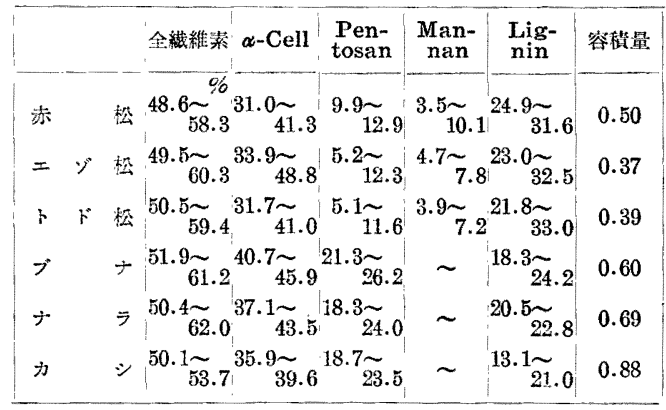

先ずパルプ枋として適材かどらかの重要な要素とし て考兄られますのは「木材成分」及び「形態的な様相」 であると思われますが，見在使用されている主要原木 の木材成分汇就いて比較してみ未すと第 10 表の如く であります。

広葉材梳針葉材に比較して，成分的には 人ーセルローズを主としてセルローズ成分が多く， リグニン含有量が相当少ない。

ヘミセルローズとしてペントーザンは約 $10 \%$ 多 いが，針葉樹汇あるマンナンは殆んどない。

原木中のセルローズ重合度は針葉樹程の高重合度 部分はなくむしろ均一である。

組織が密で容積重が大きい。 また形態的様相の差異として

針葉樹が仮導管を構成主成分であるのに対し，㕕 葉樹は木㵶維の他溥管柔軟細胞を混在している。

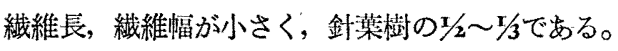
等が大きな相異として考号られます。 双て此等の特徵は溶解パルプ製造の目的から見まし た場合

リグニンが少ないという事はそれだけリグニン溶 出の薬品作用が温和で济みセルローズに対する損鹪 度が少なく以降の工程に役立つ。

ペントーザンは多いが, 酸加水分解速度がセルロ 一ズより大きいので蒸解に於いて容易に除去され， 且つ，アルカリに対する抽出性はマンナンより抵抗 性が少ないので裴造されたパルプ巾のへミセルロー ズ含有量は殆んど差がありません。

原木中に高重合度分のセルローズがないので，重 合度分布的に均一なるものが出来得る可能性が多い。

組織が密で容積重が大きい事は蒸解液の渗透汇就 いて考虑さえすれば，蒸解は容易であり，容程重の 大きいことが却ってパルプ歩留に刘する利点となる。

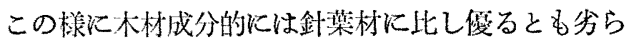
ぬ性質をもって赫りすす。

次に広葉樹パルプの唯一の久点として形態的不均一 性, 繊維長の短いことがパルプ使用面, 特にスラリー 適性上針葉樹パルプに比し劣っている大きな原因とな っていることは認めざるを得ません。

この栐なパルプ使用上，特沉スラリー操業上の難点 は御使用になる操業条件，例㓪ばスラリ一温度，パル プ濃度及び压㩁速度等に於いて，広葉樹パルプに適応 した条件を全面的棌用して戴く事により，或る程度 は克服可能な性格のあのであります。

其の他, 一般ビスコース品質, 可紡性及び糸の品質 等汇就いては，針葉樹パルプに比較して殆えぞ相異が 認められて打りませんし，実纓と致しましても，ビス コース中に広葉樹䊼維混合量の多い極めて，優秀なる 絡が生産されて战りまして, 吾々パルプメーカーとし て誠に心強く感じておる次第であります。

以上申し上げた様に，単に往来迄の同一使用法で針 葉樹パルプと広葉樹パルプとを比較して見ますと，使 い易さと言う点では遜色のある事は吾々も十分認識す る処でありますが，原木事情，原木価格，其の他現在 の経済的諸情勢より見て，ビスュース品位を低下させ ずに出来る限り安価なパルプを供給する事が，パルプ メーカーとしての最大の責㹢と信じますので, 使用者 側に於か水ましても，十分な御理解と御研究の下沅， 広葉樹溶解パルプを使いこなして戴き共存共栄の契を 学げる様, 御願い申し上げる次第でございます。 